Tavşanlı, Ö. F. (2018). İlkokul öğrencileri ne yazar? : İlkokul öğrencilerinin yazılı anlatımlarında metin türü, konu ve içerik tercihlerinin incelenmesi. Ana Dili Eğitimi Dergisi, 6(1), 32-47.

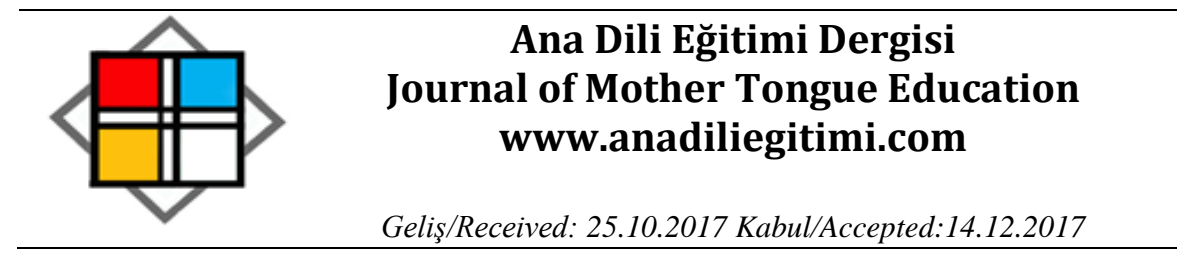

\title{
İlkokul Öğrencileri Ne Yazar? : Illkokul Öğrencilerinin Yazılı Anlatımlarında Metin Türü, Konu ve İçerik Tercihlerinin İncelenmesi*
}

Ömer Faruk TAVŞANLI**

\begin{abstract}
Öz
Bu araştırmanın amacı ilkokul öğrencilerinin yazılı anlatımlarında tercih ettikleri metin türü ve yazma konularını/içeriklerini incelemek ve bu tercihlerinin altında yatan sebepleri ortaya çıkarmaktır. Araştırmada nitel araştırma desenlerinden biri olan betimleyici fenomenoloji deseni kullanılmıştır. Araştırmanın çalışma grubunu ilkokul 2. sınıfta öğrenim görmekte olan 20 öğrenci oluşturmaktadır. Bu çalışmada veriler yarı yapılandırılmış görüşme soruları ile toplanmış ve verilerin analizinde içerik analizi yöntemi kullanılmıştır. Araştırmanın sonuçlarına göre, öğrencilerin daha çok ikna edici bilgilendirici metin yazmayı tercih ettikleri görülmüştür. Öğrencilerin hiçbiri gerçek yaşamdan öyküleyici metin ve şiir yazma türlerini tercihleri içerisinde ifade etmemiştir. Öğrencilerin yazma konusu olarak daha çok sosyal aktivite, aile, zararlı alışkanlıklardan korunma, arkadaş, gezi, hayvanlar, oyuncak ve öğretmen ile ilgili metinler yazmayı tercih ettiklerini ifade ettikleri görülmüştür. Öğrenciler yazının içeriğini ise genel olarak komik olayların ve macera olaylarının şekillendirdiğini ifade etmiştir.
\end{abstract}

Anahtar Sözcükler: Yazma tercihi, metin türü, metin konusu, metin içeriği

\section{What do Primary School Students Write about? : Investigation of Text Types, Subjects and Content Preferences in the Written Works of Primary School Students}

\begin{abstract}
The purpose of this research was to examine the types of texts and topics/content that primary school students prefer in their written works and to reveal the underlying causes for those preferences. Descriptive phenomenology which is one of the qualitative research methods was used in the study. The study group consisted of 20 second-grade students. The data were collected, using semi-structured interview questions and the content analysis method was used for data analysis. According to the results of the study, the students preferred to write persuasive and expository texts more. None of the students expressed narrative texts or poetry as their preferences. It was observed that students preferred to write texts about social activities, family, bad habits, friends, trips, animals, toys and teachers. Students also stated that in general funny events and adventures formed the essence of their writings.
\end{abstract}

Key Words: Writing preference, text type, text subject, text content

\footnotetext{
${ }^{*}$ Bu çalışmanın bir bölümü 16. Uluslararası Sınıf Öğretmenliği Eğitimi Sempozyumunda Sunulmuştur.

${ }^{* *}$ Araştırma Görevlisi, Uludağ üniversitesi Eğitim Fakültesi Sınıf Öğretmenliği Eğitimi $A B D$, omerfaruktavsanli@gmail.com
} 


\section{Giriş}

Günümüzde öğrencilerle gerçekleştirilen yazma çalışmalarında genel olarak süreç temelli yazma yaklaşımının kullanılması tavsiye edilmektedir (Calkins, 1986; Willis, 2001). Süreç temelli yazma yaklaşımı pek çok araştırmacı tarafından, iyi bir yazma öğretiminde bulunması gereken aşamaların olduğu ve bu aşamaların dikkate alınarak yazma öğretiminin planlanması gerektiği şeklinde açıklanmıştır (Emig, 1971; Graves, 1983; Murray, 1984; Flowers \& Hayes, 1981). Bu aşamalar; yazma öncesi hazırlık ve planlama, taslak yazı oluşturma, gözden geçirme ve kontrol, gözden geçirme doğrultusunda düzenleme ve paylaşma aşamalarından oluşmaktadır (Calkins,1986; Willis, 2001; Karatay, 2011; Arıcı \& Kaldırım, 2015; Seban, 2016).

Öğrencilerin yazacakları konuyu kararlaştırma, yazacağı konu ile ilgili hazırlık çalışmaları yapma ve yazacaklarının sınıını belirleme gibi çalışmalar yazma öncesi hazırlık ve planlama aşamasında ele alınmaktadır. Bu aşamada dikkat edilmesi gereken en önemli hususlardan biri öğrencilerin seçecekleri konuyu belirlemesinde özgür bırakılmaları gerekliliğidir. Bu durum öğrencilerin metnin içeriğini kendilerinin yönetebilmesi ve yazacağı metne karşı sahiplik duygusu yaşamasında önemli bir etken olarak görülür. Tahmin edilebileceği gibi öğrencilere böyle bir özgürlük tanındığında, öğrenciler en iyi bildikleri ve en rahat yazabilecekleri konuları tercih edeceklerdir. Bu durum yalnızca çocuklar için değil, yetişkinler için de söz konusudur. Öğrenciler kendi deneyimledikleri, yaşadıkları ya da merak ettikleri konuları; başkalarının merak ettiği, deneyimlediği ya da yaşadığı konulara göre daha istekli yazarlar (Graves, 1983). Buradan hareketle öğrencilere belli bir konu vererek yazı yazmalarını istemek, onların yazmaya yönelik motivasyonlarını düşürücü bir etken olarak karşımıza çıkmaktadır.

Küçük yaştaki çocuklarla yazma çalışmaları yaparken öğrencilerin kendi seçtikleri ve deneyimlerini aktararak daha rahat yazabilecekleri konularda yazma çalışmaları gerçekleştirmenin öğrencilerin yazma becerilerinin gelişimine ciddi katkılar sağlayacağı düşünülmektedir (Chaney, 2011). Öğrenciler yazma çalışmaları yapacakları konuyu kendileri belirlediğinde detaylara daha çok hâkim olacakları için yazılarındaki bütünlüğü korumak kolay olacaktır. Ayrıca yaşadıkları ve deneyimledikleri olayları yazıya geçiren öğrencilerin süreci bizzat kendileri yaşadıkları için planlama yapma noktasında kendilerine daha fazla güvenecekleri tahmin edilmektedir (Lee, 1987; Ruddell, 2006). Öğrencilerin bu şekilde yazdıkları yazılar, onlara çevreleriyle iletişim kurma hissini yaşatacağından, bu durumun öğrenciler için ekstra motivasyon kaynağı olacağı belirtilebilir. Süreç temelli yazma yaklaşımının son aşaması olan paylaşma aşamasında yazılan yazıların yakın/uzak çevre ile paylaşııması gerekmektedir. Bu noktada öğrenci kendi yaşadığı bir deneyimi çevresi ile paylaşarak onların bu deneyimden haberdar olmasını sağlayacak ve kendini daha mutlu hissedecektir (Dyson, 1995). 
İlkokul Öğrencileri Ne Yazar? : İlkokul Öğrencilerinin Yazılı Anlatımlarında Metin Türü, Konu ve İçerik Tercihlerinin Incelenmesi*

Öğrencilerin yazma becerilerinin gelişimleri birbirlerine göre farklılık göstermektedir. Bunun nedenlerinden biri öğrencilerin yazdıkları konu hakkında sahip oldukları bilgi düzeyinin farklı olması olarak gösterilmektedir (McCutchen, 1986). Öğrenciler yazma çalışmaları yaparken daha fazla bilgi sahibi oldukları konularda yazı yazmayı istemektedir. Dolayısıyla öğrencilerden kendi seçtikleri bir konu dışında daha önceden belirlenmiş bir taslak verip onunla ilgili yazma çalışmaları yapmalarını istemek, o konuda hepsinin farklı bilgi düzeyine sahip olacağı gerçeğinden hareketle doğru bir yaklaşım olmayacaktır. Çünkü bu durum bir konuda daha fazla bilgi sahibi olan öğrencilerin diğer öğrencilerden çok daha iyi metin üretmesine sebep olacak ve bir grup öğrencide başarısızlık hissi uyandıracaktır. Örneğin futbol veya daha çok erkeklerin oynadığı bir oyun hakkında öğrencilerden yazma çalışmaları yapmalarını istemek kız öğrencilerin bu çalışmaya doğrudan negatif olarak başlamalarına sebep olacaktır.

Öğrencileri yazma çalışmaları yapacakları konularda özgür bırakmanın bir diğer sebebi ise her öğrencinin farklı ilgi alanlarına sahip olduğu gerçeğidir. Tüm bireylerin olduğu gibi yaş düzeyi küçük de olsa ilkokul öğrencilerinin de ilgi duyduğu alanlar bulunmaktadır. Bu noktada öğrencilerin ilgi alanları göz önüne alınarak onlara yazma çalışması yaptırmak önemli bir durum olarak dikkat çekmektedir. Çünkü öğrencilere yazma çalışmalarını sevdirmenin pek çok koşulu olsa bile onların ilgi alanlarını göz önünde bulundurarak yazma çalışmalarını sürdürmek süreç içerisinde daha ön plana çıkmaktadır (Arıcı \& Ungan, 2008). Bu bakımdan öğrencilere bir konu vererek onları kısıtlamanın, verilen konunun mutlaka öğrencilerin bir kısmının ya da büyük bir çoğunluğunun ilgi alanı dışında olacağı düşünülürse yanlış olduğu görülebilmektedir. Öğrencilerin ilgi duydukları ve istedikleri bir konuda yazmalarının onların performansını artırdığı unutulmamalıdır (Seban, 2016).

Öğrencilerin yazma çalışmalarında yazacakları metnin türü, konusu ve içeriği ile ilgili çalışmalar genel olarak cinsiyet bağlamında ele alınmıştır (Peterson, 2006). Araştırmacılar öğrencilerin yazılarında kullanacakları konu ve içerik tercihlerinin yazarın cinsiyetinden bağımsız olarak düşünülemeyeceğini ifade etmişlerdir (Kamler, 1993; Seban, 2016). Bu konuda yapılan çalışmalarda kız öğrencilerin oyuncak, giyim kuşam ve alışveriş gibi konuları; erkeklerin ise çizgi film kahramanları, süper kahramanlar, oynadıkları bilgisayar oyunları ve arabalar gibi konuları tercih ettikleri görülmüştür (Keenan, Solsken \& Willet 1999). Kız öğrenciler yazılarında daha çok kendi yakınsak alanları içerisine giren olayları yazmayı tercih ederken, erkek öğrenciler ise daha çok uzak çevreleriyle ilgili yazılar yazmaya yatkın görünmektedir (Freedman, 1995; Peterson, 2000). Bu açıdan bakıldığında öğrencilerin yazılarında kullanacakları metin türü, konu ve içeriğinin yazarın cinsiyet değişkeninden bağımsız olarak düşünülemeyeceği ortaya çıkmaktadır.

Alanyazın incelendiğinde öğrencilerin yazma çalışmaları yaparken seçecekleri konuyu belirlemenin önemi üzerinde ciddi bir şekilde durulduğu görülmektedir (Lee 1987; Flowerday, Schraw 
\& Stevens 2004). Bu noktada ilkokul öğrencilerinin hangi konu, içerik ve metin türlerinde yazma çalışmaları yapmayı sevdiğini belirlemenin ilkokul öğretmenlerine, velilere, eğitim politikalarını düzenleyen görevlilere, eğitim programcılarına ve yazma eğitimi ile ilgili çalışma yapan araştırmacılara yazma öğretiminde konu seçimi ile ilgili teorik ve pratik bilgi sağlayarak bu konuda yapılacak uygulama, program geliştirme ve akademik çalışmalara yol göstermesi açısından değerli olacağı ortaya çıkmaktadır. Çünkü okuryazarlık eğitimi öğrenmenin temelini oluşturmaktadır. Yapılan çalışmalar öğrencilerin okuryazarlık becerilerinin onların hem günümüzdeki akademik başarıları üzerinde hem de gelecekteki başarılarının sınırlarını belirlemede oldukça etkili olduğunu ortaya koymaktadır (Shatil, Share \& Levin, 2000; Aram 2005; Bloodgood, 1999; Blair \& Savage, 2006; Beach \& Ward, 2013; Gerde, Bingham \& Wasik, 2012; Smith, 2008; Collier, 2010; Seban \& Tavşanlı, 2015). Buradan hareketle araştırmanın amacı ilkokul öğrencilerinin yazılı anlatımlarında tercih ettikleri metin türü ve yazma konularını/içeriklerini incelemek ve bu tercihlerinin altında yatan sebepleri ortaya çıkarmak olarak belirlenmiştir. Bu bağlamda aşağıdaki araştırma sorularına yanıt aranmıştır:

- Öğrenciler yazılı anlatımlarında hangi metin türünü tercih etmektedir? Niçin? (örn. Bilgilendirici metin, şiir)

- Öğrenciler yazıı anlatımlarında hangi konularda yazmayı tercih etmektedir? Niçin? (örn. Oyun anlatma, katıldığı bir kutlamayı anlatma)

- Öğrenciler yazılı anlatımlarında hangi içerik türünü tercih etmektedir? Niçin? (örn. Mizah, macera)

\section{Yöntem}

$\mathrm{Bu}$ araştırmada nitel araştırma desenlerinden biri olan betimleyici fenomenoloji deseni kullanılmıştır. Bireylerin aslında bildiği şeylerin ne olduğu ve bunu nasıl anlamlandırdıkları ile ilgilenen betimleyici fenomenoloji epistemolojik bir bakış açısına sahiptir (Ersoy, 2016). Bu yöntem bireylerin ya da grupların bir durum, kavram ve olguyu kendi yaşantıları doğrultusunda nasıl algıladıkları ve yorumladıkları üzerine odaklanır (Reiners, 2012; Christensen, Johnson \& Turner, 2015). Betimleyici fenomenoloji farkında olsak bile tam olarak anlamada ve çözümlemede zorluk yaşadığımız durumların derinlemesine incelenmesine imkân sağlamaktadır (Creswell, 2012; Sart, 2015). Böylece araştırılan olgunun çok boyutlu olarak yorumlanarak, farklı bakış açıları ile değerlendirilmesi sağlanmaktadır (Christensen, Johnson \& Turner, 2015). Bu çalışmada ele alınan ve anlaşılmaya çalışılan durum; ilkokul öğrencilerinin yazılı anlatımlarında tercih ettikleri yazma konusu, içeriği ve metin türü ile bunların altında yatan sebeplerdir. 
Illkokul Öğrencileri Ne Yazar? : Illkokul Öğrencilerinin Yazılı Anlatımlarında Metin Türü, Konu ve İçerik Tercihlerinin İncelenmesi*

\section{Katılımcilar}

Fenomenolojik çalışmalarda araştırma grubu, araştırmanın odaklandığı konuda deneyimleri olan ve bu deneyimlerini aktararak açıklayabilecek kişilerden oluşturulmaktadır. Araştırmanın çalışma grubu seçilirken amaçlı örnekleme yöntemlerinden olan ölçüt örneklemesi kullanılmıştır. Bu örnekleme yöntemi, önceden tespit edilmiş ölçütlere uygun kişilerin araştırmaya dâhil edilmesi gerektiği ilkesine dayanmaktadır (Christensen, Johnson \& Turner, 2015). Bu araştırma için belirlenen ölçütler öğrencilerin farklı metin türlerinde, farklı konularda ve içeriklerde yazılar yazmış olmasıdır. Bu sebeple yapılan araştırmada çalışma grubunu ilkokul 2. sınıfta öğrenim görmekte olan 20 öğrenci oluşturmaktadır. Bu öğrencilerin $10^{\prime}$ u kız 10'u ise erkek öğrencilerden oluşmaktadır. Öğrencilerle görüşülmeden önce, süreç temelli yazma yaklaşımı dikkate alınarak hazırlanan bir yazma programı altı ay boyunca öğrencilere uygulanmıştır. Bu program aracılığı ile öğrenciler metin türlerini tanıyarak farklı içerikte/konularda yazılar yazmış ve böylece görüşmeler öncesi öğrencilerin bu konuda deneyim yaşaması sağlanmıştır. Öğrenciler ile gerçekleştirilen yazma programı sonucunda 120 metin üretimi gerçekleşmiştir. Bu metinlerin 40 tanesi bilgilendirici metin, 40 tanesi öyküleyici metin, 40 tanesi ise şiirdir. Yazılan metinler konularına ve içeriklerine göre farklılık göstermektedir. Bu aşamada araştırmanın amacı doğrultusunda öğrencilere mümkün olduğunca farklı konu ve içerikte yazılar yazdırılmıştır. Böylece öğrencilerin farklı metin türleri ile pek çok konu ve içerikte yazılar yazması sağlanmıştır.

\section{Veri Toplama Aracı}

Bu çalışmada veriler yarı yapılandırılmış görüşme soruları ile toplanmıştır. Yarı yapılandırılmış görüşme soruları hazırlanırken öncelikle sınıf öğretmeni olarak görev yapan üç öğretmen ve on öğrenci ile ön görüşmeler gerçekleştirilmiş ve öğrencilerin yazma düzeyleri, yazma ilgileri, yazma konu ve içerik tercihleri ile metin türlerine yönelik farkındalıkları hakkında bilgi alınmıştır. Bu bilgiler ve alanyazın dikkate alınarak ilk etapta 9 soru hazırlanmış ve Türkçe Eğitimi alanında uzman üç akademisyenin ve 20 yıllık mesleki deneyimi olan üç sınıf öğretmeninin görüşüne sunulmuştur. Uzmanlardan gelen düzeltme ve öneriler doğrultusunda araştırmanın kapsamı dışında olduğu anlaşılan bir soru çıkarılmış ve iki soru ise tek soru olacak şekilde birleştirilmiştir. Bu doğrultuda görüşme sorularına 7 sorudan oluşmak üzere geçerlilik çalışması öncesi son şekli verilmiştir. Bu aşamadan sonra görüşme sorularının geçerliliğini sağlamak adına beş öğrenciyle yüz yüze görüşülmüştür. Bu görüşmeler esnasında iki sorunun öğrenciler tarafından aynı algılandığı tespit edilmiş ve bu iki soru birleştirilerek tek soru olacak şekilde 6 sorudan oluşan görüşme formu uygulama öncesi son halini almıştır. 


\section{Verilerin Analizi}

Bu çalışmada metindeki sözcüklerin, kavramların ve karakterlerin, kullanıldıkları bağlam içerisinde ne demek istediğini anlamak ve dile getirilen söylemlerin altında yatan ilişkileri ortaya çıkarmak amacıyla içerik analizi yöntemi kullanılmıştır (Merriam, 1998; Kızıltepe, 2015).

Çalışma, 20 öğrenciyle yüz yüze görüşülerek yapılmış ve görüşmeler ses kaydına alınmıştır. Öğrencilerle 2016-2017 eğitim-öğretim yılı bahar döneminde Serbest Etkinlik ders saatlerinde görüşülmüştür. Ses kayıtlarından elde edilen veriler öncelikle yazılı metne dönüştürülmüştür. Verilerin analizi araştırmacı ve alanda uzman iki akademisyen ile gerçekleştirilmiştir. Illk önce tüm araştırmacılar ayrı ayrı tüm verileri analiz etmiş, daha sonra bir araya gelinerek analiz sonuçları karşılaştırılmıştır. Yapılan karşılaştırma sonucunda araştırmacıların tüm temaları ortak olarak bulduğu fakat alt temalarda bazı farklılıklar olduğu dikkat çekmiştir. Bunun üzerine araştırmacılar bir araya gelerek farklı bulunan alt temalar üzerine tartışmış ve görüş birliğine varılarak temalar ile alt temalar netleştirilmiştir.

\section{Bulgular ve Yorum}

Araştırmanın bu bölümünde ilkokul öğrencilerinin yazılı anlatım eserlerinde tercih ettikleri metin türü ve yazma konuları/içerikleri hakkındaki görüşleri sunulmaktadır. Elde edilen verilere göre, öğrencilerin 3 tema altında 64 söylem dile getirdiği görülmektedir. Bu temalar; "öğrencilerin yazılarında kullandıkları metin türü tercihi”, "öğrencilerin yazılarında kullandıkları yazma konusu tercihi" ve "öğrencilerin yazılarında kullandıkları yazma içerikleri tercihi" şeklindedir.

Öğrencilerin, yazılarında kullandıkları metin türü tercihi teması altında 26 söylem dile getirdikleri görülmüştür. Bu noktada unutulmaması gereken husus ilkokul düzeyindeki öğrencilerin ilkokul öğrenimleri sürecinde üç metin türü ile karşı karşıya olduklarıdır. Öğrencilerle görüşülmeden önce üç metin türü ile ilgili de yazma çalışmaları yapılmıştır. Yani görüşmeler aracılığı ile öğrencilerden elde edilen veriler öğrencilerin birebir deneyimledikleri süreçler hakkında bilgi vermektedir. Öğrencilerin yazılarında kullandıkları metin türü tercihini yansıttıkları görüşler Tablo 1'de görülmektedir.

Tablo 1. Öğrencilerin Yazılarında Kullandıkları Metin Türü Tercihleri

\begin{tabular}{|c|c|c|}
\hline \multirow[t]{2}{*}{ Öğrencilerin Yazılarında Kullandıkları Metin Türü Tercihleri } & \multicolumn{2}{|c|}{ f } \\
\hline & Kız & Erkek \\
\hline Bilgilendirici (ikna edici metin) & 7 & 7 \\
\hline Öyküleyici (kurgu) & 2 & 5 \\
\hline Bilgilendirici & 4 & 1 \\
\hline
\end{tabular}


İlkokul Öğrencileri Ne Yazar? : İlkokul Öğrencilerinin Yazılı Anlatımlarında Metin Türü, Konu ve İçerik Tercihlerinin Incelenmesi*

Tablo 1 incelendiğinde öğrencilerin yazma çalışmaları yaparken daha çok ikna edici metin tarzında yazılmış bilgilendirici metin türünü tercih ettikleri görülmektedir. Öğrenciler ikna edici bilgilendirici metin türünden sonra en çok kurgu öyküleyici metin türünü tercih ettiklerini dile getirmişlerdir. Burada dikkat çekici olan nokta hiçbir öğrencinin gerçek yaşamdan hareketle öykü yazmayı tercih ettiğini dile getirmemiş olmasıdır. Son olarak ise öğrenciler salt bilgi vermek amaçlı bilgilendirici metinleri tercih ettiklerini ifade etmişlerdir. Öğrencilerden hiçbirinin şiir yazmayı tercih etmemesi incelenmesi gereken bir konu olarak dikkat çekmektedir. Bir diğer dikkat çekici nokta ise öğrencilerin bilgilendirici metinleri, öyküleyici metinlere göre daha çok tercih etmeleri durumudur. Öğrencilerin cinsiyet durumlarına göre tercihleri incelendiğinde kurgu öyküleyici metinleri daha çok erkek öğrencilerin, salt bilgi verme amaçlı bilgilendirici metinleri ise kız öğrencilerin tercih ettiği görülmüştür. Öğrencilerin yazılarında kullandıkları metin türü tercihlerine yönelik görüşlerinden örnekler aşağıda sunulmuştur:

A: “ Birisini ikna etme yazısında. Daha istediğimiz şeyi belki mesela bir oyuncak istiyorsun onu almak istediğinde anneni ikna ediyorsun böyle. Sonra bir şey alınca da mutlu oluyorsun. İşte ben de onun için ikna edici yazıları seviyorum."

F: “ikna etme yazısında öğretmenim. íkna yazısı yazmak güzel, çünkü istediğin bir şeyi alabiliyorsun. Ya da biri senin istediğin bir şeyi yapabiliyor."

C: “Hayal ürünü. Hayal ürünü yazmak en güzeli bence. Çünkü hayal etmeyi seviyorum. Öyle yazılarım daha güzel oluyor. Hikaye anlatmak çok güzel”

I: “Hayal ürünü. İyilikten bahseder. Kahraman olarak ben olurum. İçinde iyilik geçen.”

D: "Ben hepsinden keyif aldım. Ama en çok hayvanlı olan yani bilgilendirici. Çünkü onu yazarken kendimi öğretmenmiş gibi hissettim. anlatıyorsun daha iyi bilgi veriyorsun."

G: “Hayvanlı olandan. Yani bilgilendirici olan öğretmenim. O daha eğlenceli bana göre. Daha anlamlı aynı zamanda. Birilerini bilgilendirmek güzel."

Öğrencilerin birebir görüşmeler esnasında dile getirdikleri yorumlar incelendiğinde bazı noktalar dikkat çekmektedir. Öncelikle ikna edici bilgilendirici metin türünü tercih ettiğini ifade eden öğrencilerin bu yazılar aracılığı ile bazı hedeflerinin ya da isteklerinin somut hale geldiğini ifade etmeye çalıştıkları görülmüştür. Yani bu yazılar öğrencilerin bazı isteklerine ulaşmalarında aracı görevi görmüştür. Bir diğer dikkat çeken nokta ise öğrencilerin kurgu öyküleyici metin türünü tercih etmelerinin gerekçesi olarak öykülerdeki iyi kahramanlar yerine kendilerini betimleyerek o role girmelerini gösterdikleri anlaşılmaktadır. Bu durum öğrencilerin zaman zaman gerçekleştirmek isteseler bile gerçek hayatta başaramadıkları durumları yazdıkları yazılar aracılığı ile yaşamaları anlamına gelmektedir. Son olarak ise bilgilendirici metin türünü tercih ettiğini ifade eden öğrencilerin 
bu yazılar aracılığı ile öğretme kavramına gönderme yapmaları hususu önemlidir. Bu durum öğrencilerin başka kişilere bilgi sağlama ve yayma işlevinin onları mutlu ettiğini ortaya çıkarmaktadır.

Öğrencilerin yazılarında kullandıkları yazı konusu tercihi teması altında 28 söylem dile getirdikleri görülmüştür. Öğrenciler görüşme öncesi uygulamalarda 120 metin üretmiş ve pek çok konuda metinler yazmışlardır. Burada belirtilen yazma konu tercihlerinin bu 120 metin içerisinden süzülerek yapıldığı ve öğrencilerin ciddi bir şekilde deneyimledikleri bir sürecin sonucuna dayanan tercihler olduğu unutulmamalıdır. Öğrencilerin yazılarında kullandıkları konu tercihini yansıttıkları görüşler Tablo 2'de sunulmuştur.

Tablo 2. Öğrencilerin Yazılarında Kullandıkları Konu Tercihleri

\begin{tabular}{lcc}
\hline Öğrencilerin Yazılarında Kullandıkları Konu Tercihleri & $\mathbf{f}$ & Erkek \\
\hline Sosyal aktivite (resim yapma, spor yapma, parti yapma vb.) & 5 & 3 \\
Aile & 3 & 3 \\
Zararlı alışkanlıklardan korunma & 3 & 1 \\
Arkadaş & 2 & 1 \\
Gezi & 1 & 1 \\
Hayvanlar & 0 & 2 \\
Oyuncak & 1 & 1 \\
Öğretmen & 1 & 0 \\
\hline
\end{tabular}

Tablo 2 incelendiğinde öğrencilerin yazma çalışmaları yaparken başta sosyal aktivite (spor, parti, doğum günü vb.) olmak üzere aile, zararlı alışkanlıklardan korunma, arkadaş, gezi, hayvanlar, oyuncak ve öğretmen ile ilgili konularda yazma çalışmaları yapmayı tercih ettikleri görülmüştür. Öğrencilerin, hangi metin türünü kullanırlarsa kullansınlar bu konuların dışına çıkmayı çok az tercih ettikleri belirlenmiştir. Örneğin aile ile ilgili kurgu hikâye yazan bir öğrenci aile fertlerine olağanüstü güçler atfederek metnini oluşturmakta ya da sosyal aktiviteler hakkında bilgilendirici bir yazı yazan öğrenci o sosyal aktiviteyi tanımlayarak o konuda bilgi vermektedir. Cinsiyetlere göre öğrencilerin yazma konu tercihleri incelendiğinde ise sosyal aktivite, zararlı alışkanlıklardan korunma, arkadaş ve öğretmen konularının kız öğrenciler tarafından; hayvanlar konusunun ise erkek öğrenciler tarafından tercih edildiği görülmüştür. Öğrencilerin yazılarında kullandıkları konu tercihlerine yönelik görüşlerinden örnekler aşağıda sunulmuştur:

B: “Arkadaşımın doğum gününü yazarım babamla eğlence parkına gitmemizi yazarım öyle şeyler yazarım."

D: "Dedemi sigara içmemeye, anneannemi ve annemi spor yapması için."

$\mathrm{E}$ : “Mesela annem İstanbul'a gitse anneannemle evde dursam anneme özlediğimi yazarım. Sonra ne zaman geleceğini sorarım. Onu çok özlediğimi yazarım işte." 
ilkokul Öğrencileri Ne Yazar? : İlkokul Öğrencilerinin Yazılı Anlatımlarında Metin Türü, Konu ve İçerik Tercihlerinin Incelenmesi*

D: "Çok şeker yememeliyiz, çok sigara içmemeliyiz. Bunu yazmak iyi olur."

C: "Bir de hayvanlarla belgeseli çok sevdiğim için hayvanları yazmak isterdim."

F: “ Kedi almak, sevdiğim bir oyuncak almak, sevdiğim bir balon almak, teröristler ölsün diye bir de her şeyimi planlı yapmak, Çünkü mutlu hissediyorum. "

Öğrencilerin birebir görüşmeler esnasında dile getirdikleri yorumlardan hareketle daha çok yakınsak alanlarıyla ilgili konularda yazmayı tercih ettikleri görülmüştür. Bu noktada öğrencilerin yakınındaki kişilerin kötü alışkanlıklara sahip olmaları ve onlardan uzak kalmalarının öğrencileri çok etkilediği ve yazılarının konusunu şekillendirdiği ortaya çıkmaktadır. Yine aynı şekilde öğrenciler yakın çevrelerinde bulunan kişiler ile gerçekleştirdikleri eğlenceli ve sosyal etkinlikleri yazmaya daha istekli görünmektedir.

Son olarak öğrencilerin, yazılarında kullandıkları içerik tercihi teması altında 10 söylem dile getirdikleri görülmüştür. Bu tema altında dile getirilen söylem sayısının diğer temalara nazaran daha az olduğu görülmektedir. Öğrencilerin yazılarında kullandıkları içerik tercihini yansıtan görüşler Tablo 3'te sunulmuştur.

Tablo 3. Öğrencilerin Yazılarında Kullandıkları İçerik Tercihleri

\begin{tabular}{lcc}
\hline Öğrencilerin Yazılarında Kullandıkları İcerik Tercihleri & $\mathbf{f}$ & \\
& Kız & Erkek \\
\hline Komik Olaylar & 1 & 4 \\
Macera & 2 & 1 \\
Tarih & 0 & 2 \\
\hline
\end{tabular}

Tablo 3 incelendiğinde öğrencilerin yazacakları konuların içeriklerini daha çok komik olaylar üzerine şekillendirmeyi tercih ettikleri görülmüştür. Komik olaylar dışında ise macera ve tarih içerikli yazılar tercih edilmektedir. Öğrencilerin ilkokul 2. sınıf düzeyinde olduklarından komik olaylar ve macera içerikli yazılar yazmayı tercih etmeleri normal görülse bile tarih içerikli yazmaya yönelik iki söylem dikkat çekmektedir. Cinsiyetlere göre yazma içerik tercihleri incelendiğinde ise erkek öğrencilerin komik olaylar ve tarih içerikli yazıları; kız öğrencilerin ise macera içerikli yazıları yazmayı tercih ettikleri görülmüştür. Öğrencilerin yazılarında kullandıkları içerik tercihlerine yönelik görüşlerinden örnekler aşağıda sunulmuştur:

A: "Ben komik olayları yazmayı seviyorum. Böylece hem yazarken kendim gülüyorum hem de insanlar gülüyor okuyunca."

C: “ Komik yazılar yazmayı seviyorum. Çok eğlenceli çünkü. Kendim bile okuyup okuyup gülüyorum.” 
F: "Macera anlatmayı seviyorum. Maceralı şeyler güzel olur. Filmler de güzel mesela maceralı olanlar."

E: "Ben mesela eski çağları, dinozorları, eski insanları falan yazmayı severim. Çünkü onları kimse bilmiyor, ben araştırıp yazıyorum onları."

Öğrencilerle gerçekleştirilen görüşmeler dikkatli bir şekilde incelendiğinde öğrencilerin komik içerikte yazılar yazmalarının sebebi, kendilerinin ve çevrelerinde bu yazıyı okuyanların kendilerini daha mutlu hissedeceklerini düşünmeleri şeklinde belirtilebilir. Macera yazıları yazan öğrencilerin bu içerikteki diğer faaliyetleri de sevdiği ve hoşlandıkları görülmektedir. Son olarak tarih içerikli yazıların ise daha çok bilgi verme amaçlı olarak yazıldığı anlaşılmaktadır.

Elde edilen veriler genel olarak değerlendirildiğinde öğrencilerin daha çok ikna edici bilgilendirici metin yazmayı tercih ettikleri görülmüştür. Bu durumun öğrencilerin ikna edici metinleri doğrudan bir muhataba yazmaları ve bu muhatap ile etkileşim sonucunda bir netice elde etmelerinden kaynaklandığı anlaşılmaktadır. Öğrencilerin ayrıca kurgu olmak üzere öyküleyici ve bilgi vermeyi amaçlayan bilgilendirici metinleri de tercih ettikleri görülmüştür. Öğrencilerin hiçbiri gerçek yaşamdan öyküleyici metin ve şiir yazma türlerini tercihleri içerisinde ifade etmemiştir. Öğrencilerin yazma konusu olarak daha çok sosyal aktivite, aile, zararlı alışkanlıklardan korunma, arkadaş, gezi, hayvanlar, oyuncak ve öğretmen ile ilgili metinler yazmayı tercih ettiklerini ifade ettikleri görülmüştür. Öğrenciler yazının içeriğini ise genel olarak komik olayların ve macera olaylarının şekillendirdiğini ifade etmiştir. Az sayıda da olsa yazının içeriği olarak tarihî konuları seçeceğini ifade eden öğrenciler de bulunmaktadır. Bu öğrencilerin tarihî konuları ve eski çağları merak ettiğini ifade ettikleri görülmüştür. Yani bu öğrenciler kendi kişisel ilgileri ile bağlantılı olarak tarihi içerikli yazılar yazmayı tercih ettiklerini ifade etmişlerdir. Cinsiyet durumları göz önüne alındığında ise erkek öğrencilerin kurgu öyküleyici metinleri, kız öğrencilerin ise salt bilgi verme amaçlı metinleri daha fazla tercih ettiği saptanmıştır. Konu bazında sosyal aktivite, zararlı alışkanlıklardan korunma ve arkadaş konularının kız öğrenciler tarafından; buna karşılık hayvanlar konusunun ise erkek öğrenciler tarafından daha çok tercih edildiği tespit edilmiştir. Erkek öğrenciler yazılarında daha çok komik olaylar ve tarih içerikli yazılar olmasını tercih ederken bu durum kız öğrencilerde içeriğin maceraya kayması şeklinde gerçekleşmiştir.

\section{Sonuç, Tartışma ve Öneriler}

Türkiye'de ilkokul Türkçe ders programlarında süreç temelli yazma yaklaşımından faydalanılıyor olsa bile hâlihazırdaki uygulamaların ürün odaklı olarak devam etmesinden dolayı yazma öğretiminde istenilen başarı yakalanamamaktadır (Tabak \& Göçer, 2013; Tavşanlı, 2017). Süreç temelli yazma yaklaşımında konu seçiminde öğrencilerin özgür olması temele alınırken (Graves, 
İlkokul Öğrencileri Ne Yazar? : İlkokul Öğrencilerinin Yazılı Anlatımlarında Metin Türü, Konu ve İçerik Tercihlerinin Incelenmesi*

1983) ülkemizde yapılan çalışmalarda öğrencilere belli bir konu verip yazma çalışması yaptırma uygulamaları devam etmektedir (Tavşanlı, 2017).

Bu çalışmanın sonuçlarına göre öğrencilerin daha çok ikna edici bilgilendirici metinler yazmayı tercih ettiği görülmüştür. Bunun sebebi öğrencilerin ikna edici yazıları belli bir muhataba hitaben yazmalarıdır. Böylece bu yazılar aracılığıyla muhatabına ulaşan öğrenci bir iletişim sürecini aktif olarak işletmiş olmaktadır. İkna edici yazı doğası gereği muhatabını bir konuda ikna etme amacı taşıdığından bir sonuç ya da cevap alma imkânı bulunmaktadır. Bu durumun öğrencileri yazma çalışmaları yapmaları için daha fazla heveslendirdiği anlaşımaktadır. Yani öğrenciler burada yazının iletişim boyutunu ön plana çıkararak yapılan yazma çalışmasından bir sonuç alma durumunu göz önünde bulundurmuştur. Çağımlar ve iflazoğlu (2002) ile Collier (2010), öğretmenlerin görüşlerine göre yazma çalışmalarını, öğrencilerin yazma altyapılarını geliştirip iletmek istedikleri düşünceleri daha iyi aktarma yeteneği kazandırma olarak dile getirmektedir. Bu noktada yapılan çalışmada da diğer çalışmalarda (Bloodgood, 1999; Bourne, 2002; Norton, 1997) olduğu gibi yazmanın, düşünceleri ileterek kişilerarası iletişimi sağlama boyutunun önemi ortaya çıkmaktadır.

Öğrencilerin yazdıkları ikna edici metinlerin daha çok kişisel isteklerini yansıtan metinler olduğu görülmüştür. Seban (2016) yaptığı çalışmada öğrencilerin ikna edici metinlerde çok az düzeyde sosyal konuları işlediğini, genel olarak kişisel konuları tercih ettiklerini ifade etmiştir. Öğrenciler tercih ettikleri öyküleyici metinlerde ise tamamen kurgu metinler üzerinde durmuştur. Bu durum öğrencilerin kendi yaşamlarından yazılar kaleme almadığı şeklinde algılanmamalıdır. Yazılar incelendiğinde öğrencilerin çok ciddi bir oranda kendi yaşadıklarından hareketle öyküleyici metinler kaleme aldıkları ancak yazdıkları gerçekliği bir yerden sonra veya zaman zaman olağanüstü olaylar ile süsleyerek kurgu metne çevirdiği görülebilir. Bu noktada bu durum öğrencilerin gerçeklik ile kurguyu birleştirmesi olarak algılanabileceğinden olumlu bir durum olarak görülmektedir. Öğrencilerin baştan sona kurgu metin oluşturmayı tercih etmemelerinin sebebi olarak yaşadıkları önemli olayları ve yakın çevreleri hakkında yazmayı daha çok benimsemiş olmaları düşünülebilir (Kurudayıoğlu \& Karadağ 2010; Ruddell, 2006; Bourne, 2002; Willis, 2001).

Çalışmanın dikkat çekici sonuçlarından biri de öğrencilerin hiçbirinin şiir metin türünü tercih etmemesidir. Çünkü şiir, yazılması zor bir türdür ve öğrencilerin de bunun farkında oldukları düşünülebilir. Buna benzer bir yorum Kıbrıs (2008) tarafından da yapılmıştır. Kıbrıs (2008), şiir metin türünün öğrenciler için yazılması zor bir tür olduğunu belirtmiştir. Tompkins (1994) öğrencileri şiir yazarken özgür bırakmak gerektiğini, onlara illa oturmuş kıta düzeni ve uyumlu kafiyeler ile şiir yazımının dayatılmasının yanlış olduğunu ifade eder. Bu noktada özellikle küçük yaş gruplarında öğrencilerin duygularını uyumlu kafiyeler ve belli düzen içerisinde olmasa bile ifade etmeleri için onları cesaretlendirmek gerektiği ifade edilir. 
Metin türü tercihleri cinsiyet açısından ele alındığında ise erkek öğrencilerin kurgu öyküleyici metinleri, kız öğrencilerin ise salt bilgi verici metinleri daha çok tercih ettikleri görülmüştür. Metin türü ile birlikte yazılan yazıların konu tercihlerinin de kız ve erkek öğrenciler arasında farklılaştığı görülmüştür. Öğrenciler ile yapılan görüşmelere göre kız öğrencilerin, sosyal aktiviteler, zararlı alışkanlıklardan korunma ve arkadaşlık konularında, erkek öğrencilerin ise hayvanlar ve doğa konularında yazılar yazmayı tercih ettikleri görülmüştür. Seban (2016) çalışmasında yapılan araştırmanın aksine erkek öğrencilerin daha çok arkadaşlık, kız öğrencilerin ise hayvanlar konusunu tercih ettiğini dile getirmiştir. Ayrıca yine aynı çalışmada Seban (2016) kötü huylu kişilerin yaşadığı sorunlar ile baş etmesi durumunun öğrencilerin tercih ettiği konulardan birisi olduğunu ifade etmiştir. Bu durum yapılan çalışmada kötü huylu kişilerin yaşadığı sorunlar olarak değil fakat kötü alışkanlıkların giderilmesi şeklinde ortaya çıkmıştır. Yakın-uzak aile bireyleri, gezi gibi konularda ise her iki cinsiyet grubu da yazı yazmayı tercih ettiğini ifade etmiştir. Öğrencilerin yazma konusu tercihlerinde cinsiyet odaklı meydana gelen değişim yapılan bazı çalışmaların da sonuçlarını destekler niteliktedir (Kamler 1993; Fleming 1995; Freedman 1995; Simmons 1997; Peterson 2000). Kamler (1993) yaptığı araştırmada kız öğrencilerin daha çok alışveriş, oyuncak bebekler ve giyim kuşam üzerine yazılar yazmayı tercih ettiğini belirtirken erkeklerin ise oyunlar ve çizgi film kahramanları üzerine odaklandığını ifade etmiştir. Kamler'in yaptığı çalışmada elde edilen bulgular ve yapılan araştırmanın bulguları Fleming'in (1995) yazma çalışmalarının kalıplaşmış ve oturmuş cinsiyet rolleri ile uyumlu olduğu bulgusunu desteklemektedir.

Çalışmanın sonuçlarına göre öğrencilerin metinlerinde kullandıkları içeriklerin ise yine cinsiyet değişkenine göre farklılaştığı görülmektedir. Çalışmada erkek öğrencilerin yazılarının içeriklerini daha çok komik olaylar ve tarihi olaylardan oluşturduğu görülürken kız öğrencilerin macera içerikli konuları tercih ettiği görülmektedir. Bu çalışmanın sonuçlarının aksine Peterson (2000) yaptığı araştırmada kız öğrencilerin daha çok kendine yakın alanlar ile ilgili, erkek öğrencilerin ise macera içerikli yazılar yazmayı tercih ettiğini ifade etmiştir. Bu noktada böyle bir farklılığın kaynağı olarak metin oluşturma süreçlerinde etkili olan sosyokültürel değerlerin ön plana çıktığı anlaşılmaktadır. Çünkü her toplumun ve kültürün cinsiyet bazında ön plana çıkardığı değerler bulunmaktadır (Jones, 2011) ve bu değerler aynı ülke içerisinde olsa bile bölgeden bölgeye farklılık göstermektedir.

Araştırmanın sonuçları cinsiyet değişkeninin öğrencilerin yazma çalışmaları gerçekleştirirken yazılacak metin türü, metnin konusu ve içeriği konusunda ne kadar önemli olduğunu ortaya koymaktadır. Bu doğrultuda ilgili sonuçlar dikkate alınarak yazma öğretimi gerçekleştirilirken cinsiyet değişkeninin göz önüne alınmasının önemi vurgulanmıştır. Yapılan araştırma öğrencilere yazma çalışmaları yaparken yazacakları yazıların bir muhatabının olacağının ifade edilmesinin ve bu muhatabın belirlenerek yazının buna yönelik olarak yazdırımasının öğrencilerin daha istekli yazı 


\section{İlkokul Öğrencileri Ne Yazar? : İlkokul Öğrencilerinin Yazılı Anlatımlarında Metin Türü, Konu ve İçerik Tercihlerinin Incelenmesi*}

yazmasına sağlayacağını ortaya çıkarmıştır. Bu bulgunun yazma öğretimini gerçekleştiren eğitmenler açısından yol gösterici olacağı tahmin edilmektedir. Öğrencilerin ne tamamen kurgu ne de tamamen gerçek hayattan yazı yazmayı tercih etmemeleri, her ikisini aynı yazı içerisinde kullanmak istemeleri okul kitaplarını yazan ve öğretim programlarını geliştiren görevliler için göz önünde bulundurulması gereken bir husus olarak dikkat çekmektedir. Son olarak ise öğrenciler ile gerçekleştirilecek yazma çalışmalarında, onları konu seçiminde özgür bırakmanın önemi bir kez daha güçlü bir şekilde vurgulanmıştır.

Araştırma sonuçları dikkate alındığında öğretmenlere, eğitim programı düzenleyicilere ve eğitim araştırmacılarına yazma öğretiminde konu seçimi üzerine şu önerilerde bulunulabilir:

- $\quad$ Öncelikle yazma öğretimi gerçekleştirilirken öğretmenlerin konu seçiminde öğrencileri özgür bırakması gerektiği söylenebilir. Öğrencilere daha önceden belirlenmiş konularda yazılar yazdırmak onların yazmaya yönelik tutumunu olumsuz etkileyeceğinden öğretmenlerin bu tür uygulamalardan kaçınması gerekmektedir. Öğretmenlerin bu süreçte öğrencilere rehberlik ederek hangi konuda yazmalarının onlar adına daha cesaretlendirici olacağını tespit etmesi gerekmektedir. Bu noktada en önemli husus seçilecek konunun öğretmen tarafından değil, öğretmen desteği ve yönlendirmesi ile öğrenci tarafında bulunması zorunluluğudur.

- $\quad$ Araştırmada öğrencilerin şiir ve gerçek yaşamdan öykü yazma konusunda isteksiz oldukları görülmüştür. Bu noktada öğrencilerin tüm metin türlerinde nitelikli ürünler ortaya koyması hedeflendiğinden, öğrencilerin yazmaya karşı isteksiz davrandığı metin türleri ile ilgili eğlenceli yazma etkinlikleri yapılması gerekmektedir. Bu işlemin gerçekleştirilebilmesi için hazırlanan ders ve öğretmen kılavuz kitaplarının yazma öğrenme alanı ile ilgili tüm metin türlerini kapsayan eğlenceli etkinliklerden oluşturulması tavsiye edilebilir. Bu noktada, konu seçme hususunda öğrencilerin işini kolaylaştırmasından hareketle (Tavşanlı, 2017), grafik örgütleyicilerine ders kitaplarında yer verilmesi ve böylece bu örgütleyicilerin öğretim süreçlerine katılması da önerilebilir.

\section{Kaynaklar}

Aram, D. (2005). Continuity in children's literacy achievements: alongitudinal perspective from kindergarten to school. First Language, 25, 259-289.

Arıcı A. F. ve Ungan S. (2008). Konu seçiminin yazma becerisine etkisi. Çağdaş Eğitim Dergisi, 33 (357), 19-24.

Arici, A. F. ve Kaldirim, A. (2015). The effect of the process-based writing approach on writing success and anxiety of pre-service teachers. The Anthropologist, 22 (2), 318-327.

Beach, S. A. ve Ward, A. (2013). Insights into engaged literacy learning: stories of literate Identity. Journal of Research in Childhood Education, 27 (2) 239-255.

Blair, R. ve Savage, R. (2006). Name writing but not environmentalprint recognition is related to letter-sound knowledge and phonological awareness in 308 pre-readers. Reading and Writing, 19, 991-1016.

Bloodgood, J. W. (1999). What's in a name? children's name writing and literacy acquisition. Reading Research Quarterly, 34, 342-367. 
Bourne, J. (2002). 'Oh, what will miss say!': constructing texts and identities in the discursive processes of classroom writing. Language and Education, 16 (4), 241-259.

Calkins, L. M. (1986). The art of teaching writing. Portsmouth, NH; Heinemann.

Chaney, S. L. (2011). Writer's workshop: Implementing units of study, findings from a teacher study group, and student success in writing. Master dissertation, Pacific Oaks College, California.

Creswell, J. W. (2012). Educational research. Boston: Pearson.

Christensen, L. B., Johnson, R. B. ve Turner, L. A. (2015). Araştırma yöntemleri: desen ve analiz. (Çev. Ed: Ahmet Aypay). Ankara: Anı Yayıncılık.

Collier, D. R. (2010). Journey to becoming a writer: review of research about children's identities as writers. Language and Literacy, 12 (1), 147-164.

Çağımlar, Z. ve Iflazoğlu, A. (2002). Yazılı ve sözlü anlatım becerilerinin (kompozisyon) ilköğretim 5. sınıflarda öğretmen ve öğrenci görüşleri açısından değerlendirilmesi. Çukurova Üniversitesi Eğitim Fakültesi Dergisi, 23 (2), 12-22.

Dyson A. H. (1995). The courage to write: child meaning making in a contested world. Language Arts, (72), 324333.

Emig J. (1971). The composing processes of twelfth-graders. Urbana, IL 1971.

Ersoy, A. F. (2016). Fenomenoloji. Ahmet Saban ve Ali Ersoy (Ed.), Eğitimde nitel araştırma desenleri, Ankara: Anı Yayıncılık.

Fleming S. (1995). Whose stories are validated? Language Arts, 72 (8) 590-596.

Flower L. ve Hayes J. R. (1981). A cognitive process theory of writing. College Composition and Communication, $32(4), 365-387$.

Flowerday T., Schraw G. ve Stevens J. (2004). The role of choice and Interest in reader engagement. Journal of Experimental Education, 72, 93-114.

Freedman R. (1995). The mr. and mrs. club: the value of collaboration in writer's workshop. Language Arts, 72, 97-104.

Gerde, H. K., Bingham, G. R. ve Wasik, B. A. (2012). Writing in childhood classrooms: guidance for best practices. Early Chıldhood Educatıon Journal, 40 (6), 351-359.

Graves, D. H. (1983). Writing: teachers and children at work. Heinemann Educational Books, 4 Front St., Exeter, $\mathrm{NH} 03833$.

Jones S. (2011). Mapping the landscape: gender and the writing classroom. Journal of Writing Research, 3 (3),163-179.

Kamler B. (1993). The construction of gender in process writing classrooms. Ed. P. Gilbert. Gender Stories and the Language Classroom, 41-54. Victoria.

Karatay, H. (2011). Süreç temelli yazma modelleri: planlı yazma ve değerlendirme. Yazma eğitimi. Ankara: Pegem A Yayıncılık.

Keenan J., Solsken J. ve Willett J. (1999). Only boys can jump high': reconstructing gender relations in a first/second-grade classroom. Ed. B. Kamler. Constructing Gender and Difference, 33-70. Cresskill, NJ.

Kıbrıs, i. (2008). Okuma ve yazma çalışmalarında şiir etkinliklerinden nasıl yararlanılır? Abant Izzet Baysal Üniversitesi Eğitim Fakültesi Dergisi, 8 (1), 53-66.

Kızıltepe, Z. (2015). Iç̧erik analizi. Nitel araştırma yöntem, teknik, analiz ve yaklaşımlar. (Ed: Fatma Nevra Seggie ve Yasemin Bayyurt). Ankara: Anı Yayıncılık. 
illkokul Öğrencileri Ne Yazar? : İlkokul Öğrencilerinin Yazılı Anlatımlarında Metin Türü, Konu ve İçerik

Tercihlerinin İncelenmesi*

Kurudayıoğlu M. ve Karadağ Ö. (2010). Illköğretim öğrencilerinin yazılı anlatımlarının konu seçimleri açısından incelenmesi. Mustafa Kemal Üniversitesi Sosyal Bilimler Enstitüsü Dergisi, 7 (13), 192-207.

Lee J. W. (1987). Topic selection in writing: aprecarious but practical balancing act. The Reading Teacher, 41 (2), 180-184.

McCutchen D. (1986). Domain knowledge and linguistic knowledge in the development of writing ability. Journal of Memory and Language, 25, 431-444.

Merriam, S. (1998). Qualitative research and case study applications in education. San Fransisko: Jossey- Bass.

Murray D. (1984). Teaching writing as a process not product. Ed. R. L. Graves. Rhetoric and composition: a sourcebook for teachers and writers, 89-94. UpperMontclair, NJ.

Norton, B. (1997). Language and identity [Special issue]. TESOL Quarterly, 31 (3), 409-429.

Peterson S. (2000). Fourth, sixth, and eighth graders' preferred writing topics and Identification of gender markers in stories. Elementary School Journal, 101 (1), 79-100.

Peterson S. (2006). Influence of gender on writing development. Eds. C. A. MacArthur, S. Graham \& J. Fitzgerald. Handbook of writing research: New York.

Reiners, G. M. (2012). Understanding the differences between husserl's (descriptive) and heidegger's (Interpretive) phenomenological research, Journal of Nursing \& Care, 1 (5), 1-3.

Ruddell, R. B. (2006). Teaching children to read and write: Becoming an effective literacy teacher (4th ed.).Boston: Pearson.

Sart, G. (2015). Fenomenoloji ve yorumlayıcı fenomenolojik analiz. Nitel araştırma yöntem, teknik, analiz ve yaklaşımlar. (Ed: Fatma Nevra Seggie ve Yasemin Bayyurt). Ankara: Anı Yayıncılık.

Seban, D. (2016). The role of gender and grade level on topic selection in writing. Mediterranean Journal of Humanities, 6 (1), 275-285.

Seban, D. ve Tavşanlı, Ö. F. (2015). Children's sense of being a writer: identity construction in second grade writers workshop. International Electronic Journal of Elementary Education, 7 (2), 217-234.

Smith, F. C. (2008). Literacy identity development. Literacy learning: The middle years, 16 (1), 47-51.

Shatil, E., Share, D. L. ve Levin, I. (2000). On the contribution ofkindergarten spelling to grade 1 literacy: A longitudinal study in Hebrew. Applied Psycholinguistics, 21, 1-21.

Simmons J. (1997). Attack of the killer baby faces: gender similarities in third grade writing. Language Arts, 74, 116-123.

Tabak G. ve Göçer A. (2013). 6-8. Sınıflar türkçe dersi öğretim programının ürün ve süreç odaklı yazma yaklaşımları çerçevesinde değerlendirilmesi. Ahi Evran Üniversitesi Kırşehir Eğitim Fakültesi Dergisi (KEFAD), 14 (2), 147-169.

Tavşanlı, Ö. F. (2017). Evaluation of the instructional program in turkey based on the process-based writing approach. International Journal of Language Academy, 5(2), 79-97.

Tompkins, G. E. (1994). Teaching writing: balancing process and product. Macmillan College.

Willis, S. (2001). Teaching young writers feedback and coaching help students hone skills. In C. Jago (Ed.), Language arts: a chapter of the cirriculum handbook alexandria, VA: Association for Supervision and Curriculum Development.

\section{Extended Abstract}

Introduction

It is advised to use process-based writing approach in writing exercises done with the students (Calkins, 1986; Willis, 2001). Process-based writing approach was explained by various researchers as that there are some stages in a qualified writing teaching and writing teaching should be planned considering these stages (Emig, 1971; Graves, 1983; Murray, 1984; Flowers \& Hayes, 1981). These stages include preparation and 
planning before writing, building a writing draft, revising and controlling, editing in accordance with revision and sharing (Calkins,1986; Willis, 2001; Karatay, 2011; Arıcı \& Kaldırım, 2015; Seban, 2016).

The exercises such as students' decision about the writing subject, doing preparation exercises for the subject and creating the borders of their writings are handled at preparation and planning stage. One of the most important aspects that should be taken into consideration at this stage is the necessity of letting the students free for choosing the subject. This fact is seen as an important factor for managing the text context on their own and having the feeling of possession for students.

Investigating the literature, it is seen that the importance of that students determine the subject to be chosen is emphasized seriously (Lee 1987; Flowerday, Schraw \& Stevens 2004). At this point, it appears that determining in which types of subjects, contexts and texts the elementary students like to do exercises will be valuable in terms of guiding elementary teachers, parents, officials organizing educational policies, educational programmers and researchers having a study interest in writing education by providing theoretical and practical knowledge about subject selection within the context of future implementations, program development and academic studies. The studies have revealed that literacy skills of the students are quite effective in determining the borders of their both existing and future academic achievement (Shatil, Share \& Levin, 2000; Aram 2005; Bloodgood, 1999; Blair \& Savage, 2006; Beach \& Ward, 2013; Gerde, Bingham \& Wasik, 2012; Smith, 2008; Collier, 2010; Seban \& Tavşanlı, 2015). From this point of view, the purpose of the study is determined as investigating the types of texts students prefer in their written expressions and writing subjects/contexts and revealing the reasons underlying in these preferences.

\section{Method}

Descriptive phenomenology pattern from qualitative research patterns is used in this research. Descriptive phenomenology provides an opportunity for deeply investigating the situations that we have trouble in comprehending and analysing although we are aware of them (Creswell, 2012; Sart, 2015). Thus, it is provided that the research subject is interpreted in a multidimensional way and evaluated from various aspects (Christensen, Johnson \& Turner, 2015). The situation handled and intended to be understood in this study is writing subject, context and text type the students prefer in their written expressions and the reasons underlying in them.

20 students studying at $2^{\text {nd }}$ grade in elementary school create the study group of the research. 10 of the students are female and the other 10 are male. Before interviewing with the students, a writing program prepared considering process-based writing approach had been implemented for six months. The students had recognized different text types and had written texts with different contexts/subjects and thereby the students were provided with experiences about this subject before the interviews were done.

The data were collected by semi-structured interview questions and content analysis method was used for the purpose of understanding what the words, concepts and characters meant in the context they were used and revealing the underlying relationships in the discourses expressed.

\section{Result and Discussion}

It is seen that 64 discourses under 3 themes were expressed by the students. The themes are as "text type preferences the students used in their writings", "writing subject preferences the students used in their writings" and "writing context preferences the students used in their writings".

Generally evaluating the data obtained, it is seen that the students mostly prefer writing persuasiveinformative texts. It is seen that this result derives from the fact that the students directly write persuasive texts to a respondent and get a conclusion at the end of the interaction with this respondent. It has been also seen that the students prefer narrative texts including fiction and informative texts that aim to present information. None of the students expressed narrative texts from real life and poet writing types among their preferences. It has been seen that the students expressed that they mainly prefer writing texts about social activity, family, protecting from harmful habits, friend, vacation, animals, toys and teacher as writing subjects. Students expressed that funny cases and adventures generally shape the writing context. Even if just a few, there are some students expressing that they will chose historical subjects as writing context. It has been seen that the students expressed that they wonder historical subjects and ancient ages. In other words, these students expressed that they prefer writing texts including historical context relatedly with their own personal interests. Considering gender difference, it has been seen that male students mostly preferred fiction narrative texts while female students mostly preferred texts purposing only informing. Social activity, protecting from harmful habits and friend subjects were preferred by female students; on the other hand, animal subject was mostly preferred by male students in terms of subjects. Whereas male students preferred funny cases and history content texts in writings, it aroused as shifting to adventure for female students. 